\title{
A global approach to estimate irrigated areas - a comparison between different data and statistics
}

\author{
Jonas Meier, Florian Zabel, and Wolfram Mauser \\ Department of Geography, Ludwig Maximilians University, 80333 Munich, Germany
}

Correspondence: Jonas Meier (jonas.meier@1mu.de)

Received: 17 March 2017 - Discussion started: 5 April 2017

Revised: 7 January 2018 - Accepted: 8 January 2018 - Published: 9 February 2018

\begin{abstract}
Agriculture is the largest global consumer of water. Irrigated areas constitute $40 \%$ of the total area used for agricultural production (FAO, 2014a) Information on their spatial distribution is highly relevant for regional water management and food security. Spatial information on irrigation is highly important for policy and decision makers, who are facing the transition towards more efficient sustainable agriculture. However, the mapping of irrigated areas still represents a challenge for land use classifications, and existing global data sets differ strongly in their results. The following study tests an existing irrigation map based on statistics and extends the irrigated area using ancillary data. The approach processes and analyzes multi-temporal normalized difference vegetation index (NDVI) SPOT-VGT data and agricultural suitability data - both at a spatial resolution of 30 arcsec - incrementally in a multiple decision tree. It covers the period from 1999 to 2012. The results globally show a $18 \%$ larger irrigated area than existing approaches based on statistical data. The largest differences compared to the official national statistics are found in Asia and particularly in China and India. The additional areas are mainly identified within already known irrigated regions where irrigation is more dense than previously estimated. The validation with global and regional products shows the large divergence of existing data sets with respect to size and distribution of irrigated areas caused by spatial resolution, the considered time period and the input data and assumption made.
\end{abstract}

\section{Introduction}

One of the major challenges of the 21 st century will be feeding the world's growing population (Foley et al., 2011). Con- sidering increasing meat consumption and additionally the increased use of biofuel and bio-based materials leads to estimations that global agricultural production will have to double by 2050 (Alexandratos and Bruinsma, 2012; Godfray et al., 2010; Tilman et al., 2011). Separated by sector, agriculture is the largest consumer of water. $69 \%$ of the global water withdrawal from rivers, lakes and groundwater (blue water) is used for agriculture, in some regions the share can be over $90 \%$ like in Southern Asia or in the Middle East (FAO, 2014b; please note that regional designations are based on UN Geographical Regions in UN, 2013). The regional limitation of fresh water availability plays a crucial role in global agricultural production, considering that $40 \%$ of the global yields are harvested on irrigated fields (FAO, 2014a). Irrigated areas almost doubled over the last 50 years and currently constitute $20 \%$ of the harvested areas globally (FAO, 2016b). Future expansion of irrigated areas and a related increase in water consumption is expected (Neumann et al., 2011). Due to climate change in some areas agricultural water availability is expected to decrease (Strzepek and Boehlert, 2010). The low irrigation efficiency of the common irrigation techniques such as sprinkler and flood irrigation (Evans and Sadler, 2008), the unsustainable usages of limited sources like groundwater (Wada et al., 2014), the changing river regimes (Döll and Schmied, 2012) and the changing supply by snowmelt (Mankin et al., 2015; Prasch et al., 2013) underline the need for a transition towards more sustainable and efficient use of water. The UN Sustainable Development Goals clearly reflect this need to achieve food security and the sustainable development of land use (UN, 2016). For better inventorying and investigation of global and regional water cycles and as input for crop models, detailed global information on irrigated areas at high resolution is needed. 
Methods that do not rely on surveys and that are independent of statistics have been developed to identify irrigated areas (Ozdogan et al., 2010). Remote sensing can be an alternative approach for mapping irrigated areas. Previous studies showed that remote sensing data can be used to detect irrigated areas for small- and medium-scale analyses (Abuzar et al., 2015; Ambika et al., 2016; Jin et al., 2016; Ozdogan and Gutman, 2008). Vegetation indices (Ozdogan and Gutman, 2008) and climate elements, such as evapotranspiration (Abuzar et al., 2015) derived from satellite information and combined with meteorological data, have been used to determine irrigated area. Ozdogan et al. (2010) summarized different approaches for mapping irrigated areas from local to global scale.

There are only a few studies which identify irrigated areas globally (Salmon et al., 2015; Siebert et al., 2005; Thenkabail et al., 2009a). Land use classification data sets often neglect irrigated area. Some classify irrigated area as a separate class (ESA, 2015; USGS, 2000) but do not make it a focus.

A common approach to the specific mapping of irrigated area, such as provided by the Global Map of Irrigation Areas (GMIA; Siebert et al., 2005), distributes statistical data of national and subnational agricultural surveys like AQUASTAT (FAO, 2016a) to the agricultural and "other" land use classifications. However, approaches that are restricted to statistics alone are hard to verify, since statistics may include errors and multi-scale statistics hardly exist globally. For instance in some countries in Western Africa the informal irrigated areas in urban and peri-urban areas are twice the size of the official irrigated areas for the whole country (Drechsel et al., 2006). Irrigation may increase due to economic growth and a dietary shift from staple crops towards more vegetables and fruits (Molden, 2007). In fact, even 15 years ago official FAO statistics were criticized after comparing national statistics with remote-sensing-based data (Vörösmarty and Sahagian, 2000). The study of Thenkabail et al. (2009a) globally identified $43 \%$ more irrigated areas than reported in official FAO statistics. The discrepancies between those data were explained by the politicized nature of the FAO data reports and different definitions of irrigated area (Vörösmarty, 2002). The global irrigated area mapping (GIAM) undertaken by Thenkabail et al. (2009a) is a combination of meteorological data, land use classification information (forest) and remote sensing data from multiple satellite sensors. It is validated using ground truth data and Google Earth images. Thenkabail et al. (2009a) showed that the global irrigated areas might be underestimated by the official statistics. Another approach to map global irrigated areas was developed by Salmon et al. (2015). They combine statistics, climate and remote sensing data. The study also shows, although small, an underestimation by the national and subnational statistics. Salmon et al. (2015) showed that merging remote sensing data and ancillary data is suitable for irrigation mapping. Thenkabail et al. (2009b) conclude that "both remote sensing and national statistical approaches require further refinement".
The aim of this study is to test an existing statisticsbased medium-resolution irrigation map (Siebert et al., 2013) with high-resolution data from satellite observations which have since become available. We study, through extraction of likely irrigated areas from the high spatial resolution data, to what extent and where formally undetected irrigated areas show up. At first we downscale the Siebert et al. (2005) statistically based irrigation map using high-resolution remote sensing information. In the second step we derive irrigated land from agricultural suitability data combined with remote sensing information consisting of multi-temporal normalized difference vegetation index (NDVI) profiles at high spatial resolution. By following a decision tree we identify irrigated areas as showing active vegetation growth in agricultural unsuitable regions. If these irrigated areas are not reported by the official statistics they are added in the new irrigation map. Hence, the new irrigation map is not restricted to irrigated areas recognized in official reports and allows for extending these predetermined areas. Finally, we compare our results with existing global approaches as well as with regional analyses (USA, India, China) and investigate the differences with the official national and subnational statistics.

\section{Data and methods}

The basic idea of our approach is to combine different data sets providing different kind of information. The applied data sets are available at different spatial resolutions (Table 1). As a first step, the data sets are homogenized to the same spatial resolution. We decided on the high spatial resolution of $30 \operatorname{arcsec}$ (approx. $1 \mathrm{~km}^{2}$ at the Equator), since the demand for high-resolution global data is increasing in different applications (Deryng et al., 2016; Jägermeyr et al., 2015; Liu et al., 2007; Mauser et al., 2015; Rosenzweig et al., 2014) and the pixel size of approximately $1 \mathrm{~km}^{2}$ is already close to the size of large fields (depending on the region) or an agglomeration of smaller irrigated fields. For Africa and Asia, the field size of $1 \mathrm{~km}^{2}$ might be too large (Fritz et al., 2015), but usually, irrigated fields can be much bigger in size, since irrigation is often applied by large-scale farms. Small fields are agglomerated since irrigation is usually not practiced on a single field, due to high investment and installation costs of irrigation systems. The resulting data at 30 arcsec only distinguishes between irrigated and rain-fed and does not contain percentage shares.

The decision tree in Fig. 1 shows how the data sets are analyzed and formerly undetected irrigated areas are identified. As we mentioned above, the basic idea is to increase the spatial resolution of an existing global irrigation map to 30 arcsec and to extend the data set with additional identified irrigated areas. The lower grey box in Fig. 1 shows the principal of the downscaling process, where we assign the percentage values of Siebert et al. (2005) to the high-resolution pixels within a medium-resolution pixel showing the highest 


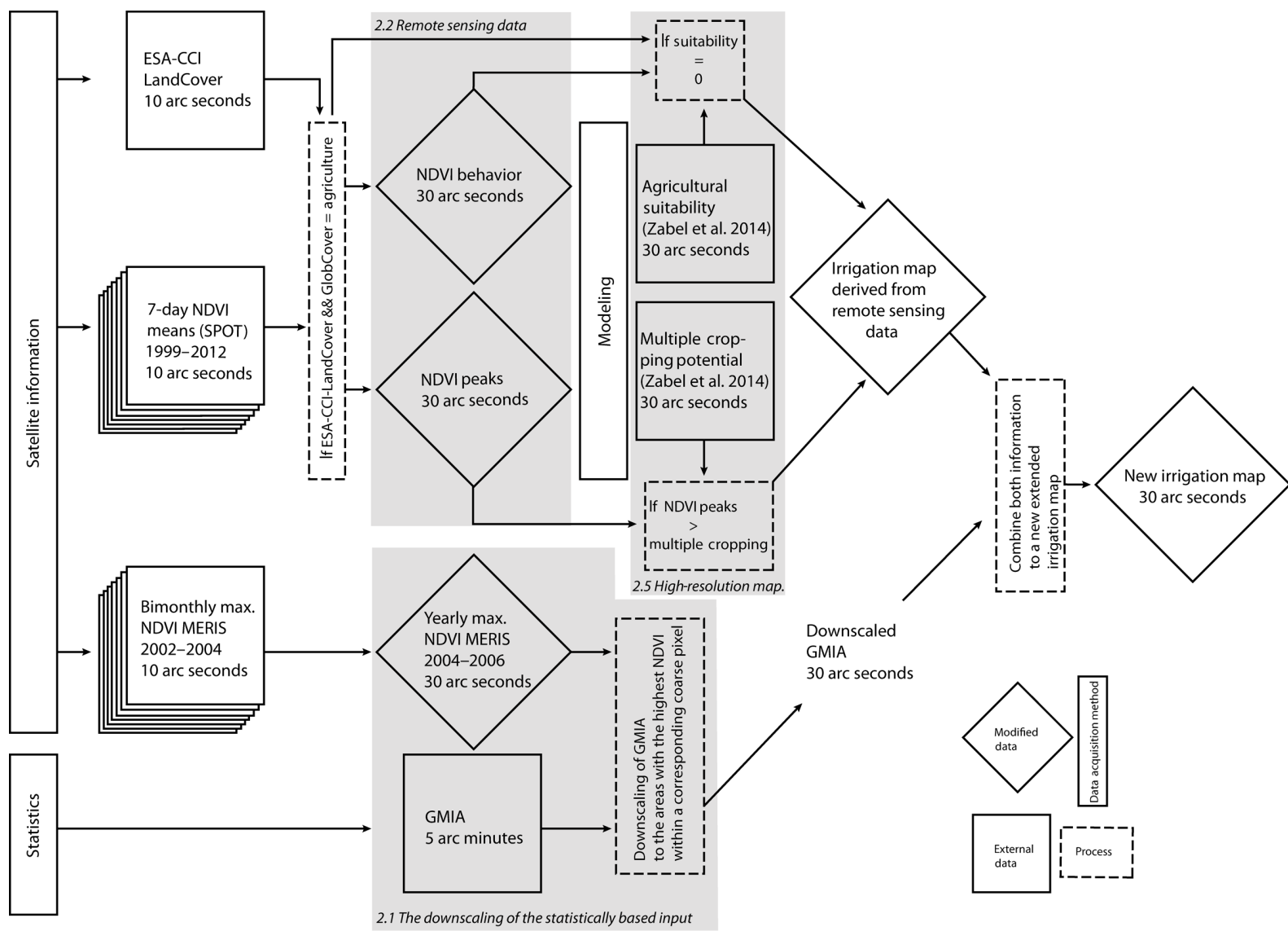

Figure 1. The scheme used for processing and analyzing the different spatial data and the multiple decision tree to determine irrigated area. The grey boxes show the described Sects. 2.1, 2.2 and 2.5.

NDVI values (see Sect. 2.1). The assigned irrigation percentages of the high-resolution pixels form the basis of our new irrigation map. The upper grey box in Fig. 1 shows the processing of the NDVI data, which is only done on agricultural areas (see Sect. 2.2 and 2.3). The processed NDVI data are compared to a global high-resolution data set of agricultural suitability (see Sect. 2.5 and the right grey box in Fig. 1). The combination of the downscaling and the comparison of NDVI and agricultural suitability results in a global highresolution irrigation map. The development of the map is described more in detail in the following section.

\subsection{The downscaling of the statistically based data set}

Siebert et al. (2005) distribute statistical data to the Global Map of Irrigated Areas (GMIA). The data set has a resolution of 5 arcmin and is available in several versions - we applied the version 5.0 (Siebert et al., 2013). To combine the different data sets to a final irrigation map at a resolution of $30 \mathrm{arcsec}$, the resolution of GMIA has to increase. For the downscaling process, shown in the lower grey box in Fig. 1, we use global bimonthly (computed once every 2 months) maximum MERIS NDVI data (ESA, 2007) at a spatial resolution of 10 arcsec and calculate the yearly maximum NDVI (Fig. 2). The bimonthly maximum NDVI data cover the period November 2004-June 2006 and represent more or less the center of the covered time period of the applied GMIA version. After upscaling the yearly maximum NDVI to 30 arcsec using a majority algorithm, the GMIA data are distributed to the areas with the highest NDVI within a corresponding coarse pixel. To avoid distributions to dense woodlands (closed tree cover $>40 \%$ ), cities and open water, these areas are excluded from the distribution, based on the ESA Climate Change Initiative Land Cover (CCI-LC) data set (ESA, 2015). Pixels with a share of irrigated area below $1 \%$ are not considered. The downscaled data set of Siebert et al. (2013) shows the irrigated area at a high spatial resolution of 30 arcsec and will in the next steps be extended by irrigated area, which are not part of the statistics yet. In the following, the downscaled data set of Siebert et al. (2013) is referred to as "downscaled GMIA".

\subsection{Remote sensing data}

This part of the decision tree is shown in the upper left grey box in Fig. 1. For the detection of the actual active vegeta- 


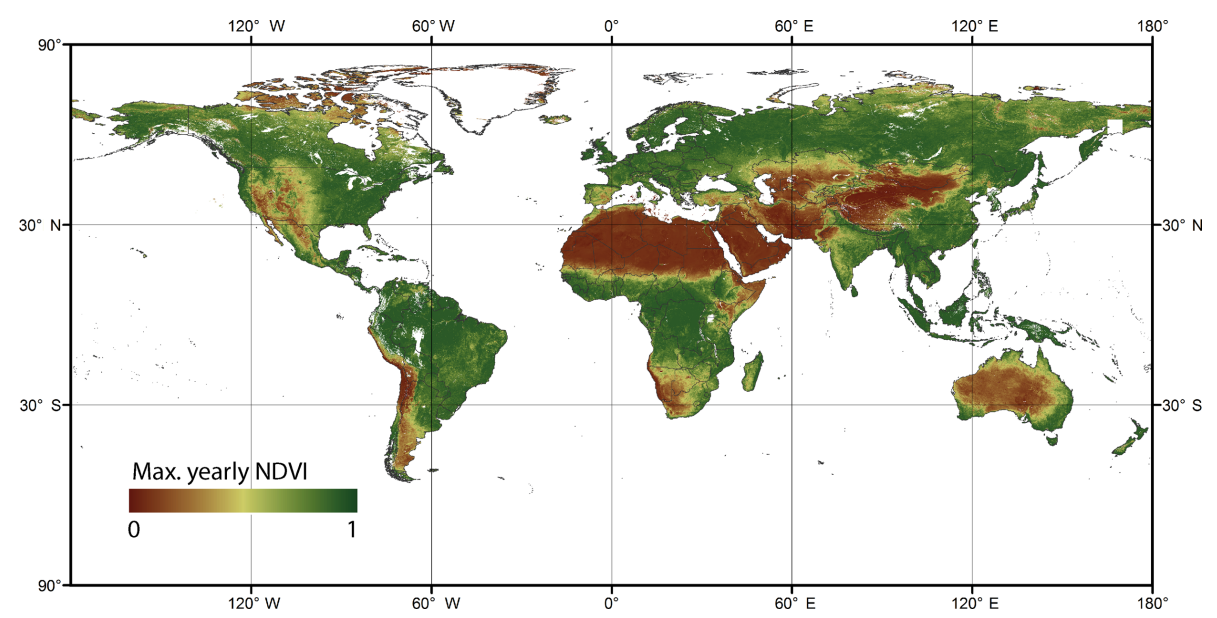

Figure 2. Yearly maximum NDVI derived from maximum bimonthly NDVI data of the EnviSAT MERIS instrument.

Table 1. Applied global data sets.

\begin{tabular}{|c|c|c|c|c|}
\hline Name & Description & Period & Resolution & Data source \\
\hline $\begin{array}{l}\text { Global Map of } \\
\text { Irrigation Areas } \\
\text { (GMIA) version } \\
5.0\end{array}$ & $\begin{array}{l}\text { Areas equipped for irrigation } \\
\text { in percent of the total pixel } \\
\text { area. }\end{array}$ & 2000-2008 & $5 \operatorname{arcmin}$ & Siebert et al. (2013) \\
\hline $\begin{array}{l}\text { Agricultural } \\
\text { suitability }\end{array}$ & $\begin{array}{l}\text { Agricultural suitability, rain- } \\
\text { fed and irrigated for the period } \\
\text { 1980-2010 }\end{array}$ & 1981-2010 & $30 \operatorname{arcsec}$ & Zabel et al. (2014) \\
\hline Multiple cropping & $\begin{array}{l}\text { Numbers of crop cycles, rain- } \\
\text { fed and irrigated }\end{array}$ & 1981-2010 & $30 \operatorname{arcsec}$ & Zabel et al. (2014) \\
\hline Maximum NDVI & $\begin{array}{l}\text { Maximum of global bimonthly } \\
\text { NDVI maxima from the } \\
\text { ENVISAT MERIS instrument }\end{array}$ & 2004-2006 & $10 \operatorname{arcsec}$ & ESA (2007) \\
\hline $\begin{array}{l}\text { 7-day mean } \\
\text { NDVI }\end{array}$ & $\begin{array}{l}\text { 7-day mean NDVI data } \\
\text { SPOT-VGT }\end{array}$ & 1999-2012 & $30 \operatorname{arcsec}$ & ESA (2015) \\
\hline $\begin{array}{l}\text { ESA-CCI-LC } \\
\text { (v. } 1.6 .1)\end{array}$ & Land classification product & 2008-2012 & $10 \operatorname{arcsec}$ & ESA (2015) \\
\hline GlobCover & Land classification product & 2009 & $10 \operatorname{arcsec}$ & ESA (2010) \\
\hline $\begin{array}{l}\text { WorldClim } \\
\text { precipitation }\end{array}$ & $\begin{array}{l}\text { Yearly reanalysis precipitation } \\
\text { data }\end{array}$ & 1961-1990 & $30 \operatorname{arcsec}$ & Hijmans et al. (2005) \\
\hline
\end{tabular}

tion we used the NDVI product of ESA-CCI (ESA, 2015). The data provide 7-day NDVI means and covers the time period from 1999 to 2012. From these data, we calculated the annual course of NDVI, averaged over the whole time period, from which we derived the number of annual NDVI peaks. In order to increase the precision of detecting active vegetation, each pixel is analyzed according to an NDVI threshold approach (Ambika et al., 2016; Shahriar Pervez et al., 2014). The chosen thresholds are a result of a comparison of different studies (Ambika et al., 2016; Shahriar Pervez et al., 2014) and the comparison of NDVI values of known irrigated and rain-fed areas. The following criteria need to be fulfilled and are shown in Fig. 3:

- The minimum NDVI has to be below 0.4, while the maximum NDVI has to be over 0.4. Since the NDVI product is a 7-day mean over 14 years, it is very likely that fields lie fallow within the time period, resulting in lower mean values. Therefore, an NDVI of 0.4 turned out to be a suitable lower threshold. This guarantees clear distinction between non-vegetated and vegetated pixels and eliminates evergreen vegetation, such as 


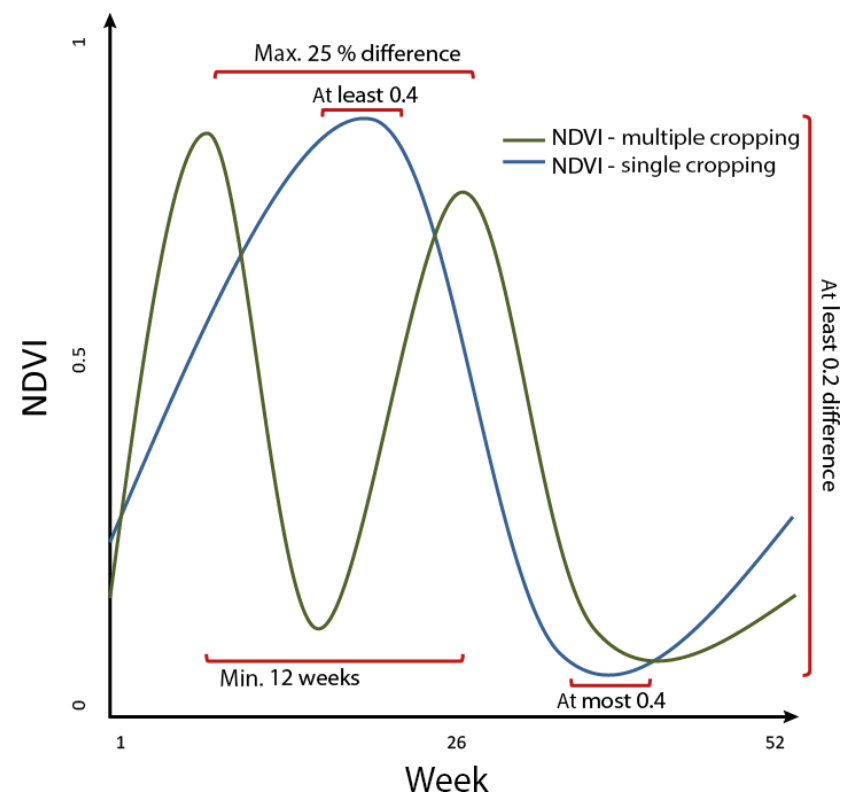

Figure 3. Idealized NDVI course of single and multi-cropping and the conditions which must be fulfilled.

forests and pasture. Thresholds like minimum and maximum NDVI used in this study have a strong effect on the result. For a global study it is difficult to find universal, transferable thresholds that can be applied globally.

- Minimum and maximum NDVI must at least differ by 0.2 to identify only pixels with a dynamic annual course that is assumed for agricultural areas.

- NDVI peaks must be at least 12 weeks apart to assign a peak to a specific growing period, assuming that the growing period length is at least 12 weeks (Sys et al., 1993). Additionally, this allows for separating multiple growing periods within a year. Often, a slight greening right after harvest was observed. This can be explained by the seeding of legumes for soil treatment, or the development of natural vegetation after harvest, which results in an increase in NDVI.

- In order to avoid classifying multiple peaks as a regular harvest, it turned out that two sequenced peaks must not differ by more than $25 \%$.

The described criteria of minimum, maximum and yearly course of NDVI and the length of growing period turned out to be robust for determining the number of crop cycles globally. The chosen criteria are suitable regarding the fact that we used 7-day NDVI means averaged over 14 years.

\subsection{Land use classification products}

The extension of irrigation is restricted to agricultural areas. The information on cropland is taken from the ESA-
Table 2. User accuracy of the applied land use data sets.

\begin{tabular}{lcc}
\hline & ESA-CCI-LC & GlobCover \\
\hline Cropland rain-fed & $88 \%$ & $82 \%$ \\
Cropland irrigated & $92 \%$ & $83 \%$ \\
Mosaic cropland $>50 \%$ & $59 \%$ & $97 \%$ \\
\hline
\end{tabular}

Table 3. List of all considered crops.

\begin{tabular}{l}
\hline Crop name \\
\hline Barley (Hordeum vulgare) \\
Cassava (Manihot esculenta) \\
Peanut (Arachis hypogaea) \\
Maize (Zea mays) \\
Millet (Pennisetum americanum) \\
Oil palm (Elaeis guineensis) \\
Potato (Solanum tuberosum) \\
Rapeseed (Brassica napus) \\
Paddy rice (Oryza sativa) \\
Rye (Secale cereale) \\
Sorghum (Sorghum bicolor) \\
Soy (Glycine max) \\
Sugarcane (Saccharum officinarum) \\
Sunflower (Helianthus annuus) \\
Summer wheat (Triticum aestivum) \\
Winter wheat (Triticum aestivum) \\
\hline
\end{tabular}

CCI-LC product (cropland rain-fed, cropland irrigated, mosaic cropland $>50 \%$; ESA, 2015) and from the predecessor GlobCover (ESA, 2010; post-flooding or irrigated croplands, rain-fed croplands, mosaic cropland; 50-70\%). According to the authors, the "accuracy associated with the cropland and forest classes" is high "and therefore a quite good result" (ESA, 2015). The user's accuracies of both data sets are shown in Table 2. The classification of cropland depends on the definition of cropland. In both data sets pasture is neither a separate class nor part of the class "grassland" or "cropland". False classification of cropland can therefore lead to false classification of irrigated areas. The combination of both data sets increases the chance of classifying irrigated areas only on cropland. Pixels that are classified as mosaic cropland in the underlying land use data sets are weighted by the averaged amount of cropland fraction for the corresponding class. All other cropland pixels are assumed to be $100 \%$ cropland.

\subsection{Agricultural suitability data}

Agricultural suitability data are taken from Zabel et al. (2014). The data describe the suitability for 16 staple, energy and forage crops (Table 3 ) according to climate, soil and topography conditions at a spatial resolution of 30 arcsec. It determines suitability for crop cultivation and the potential number of crop cycles per year, under the climate for 1981- 


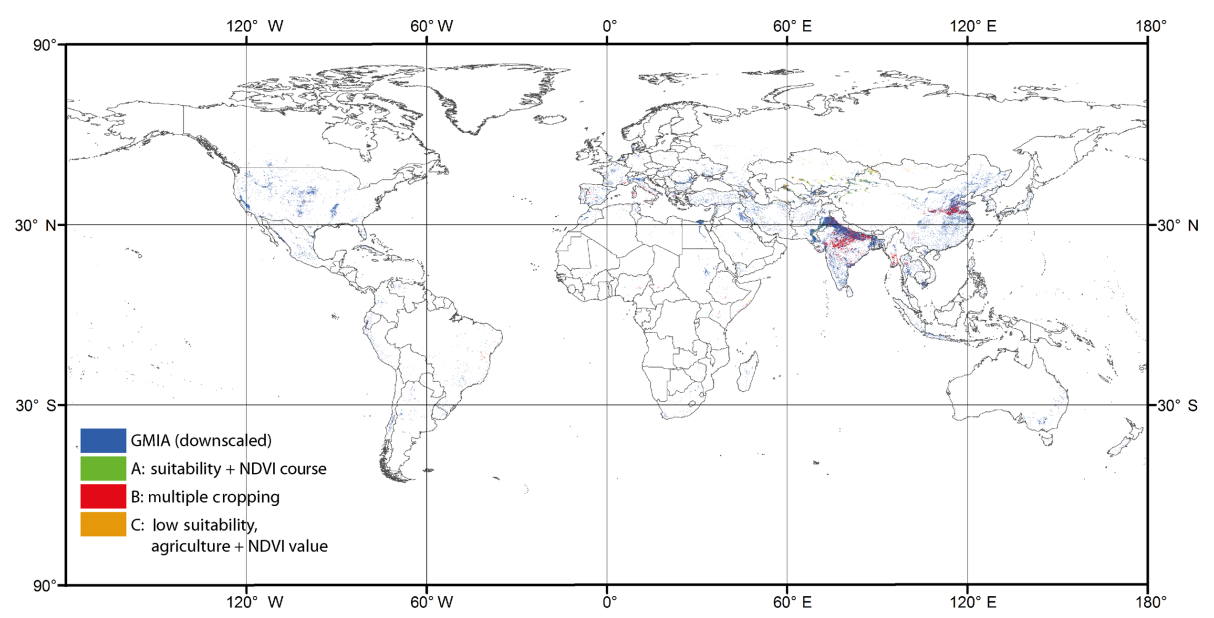

Figure 4. Irrigated areas identified by different approaches.

2010 (Zabel et al., 2014). Soil properties are not considered in this approach, because human activities may alter soil properties, for example through fertilizer and manure application or soil tillage. The data are available for past and future climate periods as well as for rain-fed and irrigated conditions separately. The data set used in this study represents for each pixel the highest suitability value over all selected crops as well as the annual course of the growing period and the potential number of crop cycles per year.

\subsection{High-resolution mapping of irrigated areas}

The downscaled GMIA data serve as a basis, providing a proven global distribution of irrigated areas. The irrigated areas which are already part of the statistics are extended with additional, previously undetected irrigated areas. The identification of the additional irrigated areas in the new irrigation map is accomplished using the criteria described above and relationships of the annual temporal NDVI profiles to the agricultural suitability. The general criterion for the identification of unknown irrigated areas is that the land use is already cropland according to ESA-CCI-LC and GlobCover. The restriction to cropland avoids the classification of irrigated areas in other land use or cover types in dry areas with high NDVI values due to lichen or weeds, since a low agricultural suitability does not exclude plant growth at all. The upper right grey box in Fig. 1 shows the assumption for irrigated areas using the NDVI and agricultural suitability data:

A. the annual NDVI course clearly suggests dynamic vegetation growth while the agricultural suitability shows a low value;

B. the number of NDVI peaks is higher than the potential number of crop cycles per year under rain-fed conditions;

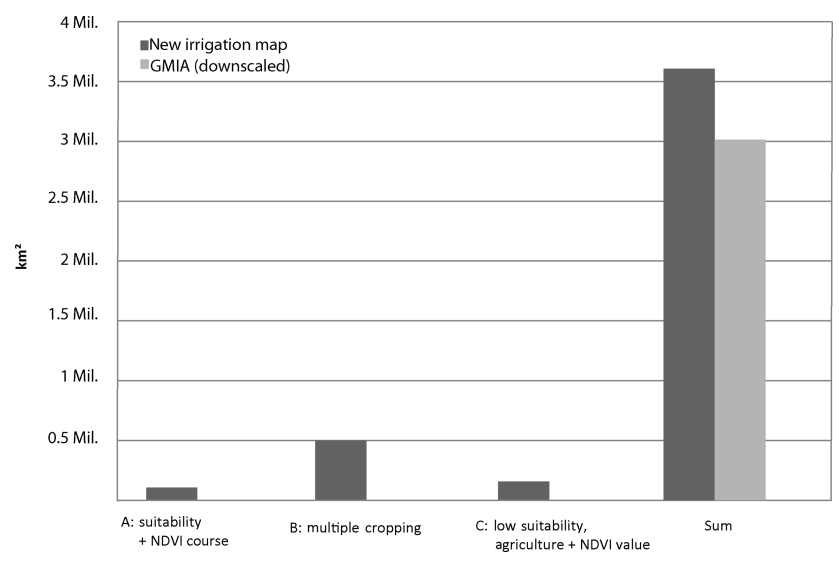

Figure 5. Results of the new irrigation map compared the downscaled GMIA.

C. land is not suitable but classified as cropland, while at the same time NDVI values and yearly courses indicate vegetation.

If one of the criteria is true, we assume the full area of the 30 arcsec pixel as being irrigated. As a result, the combination of $\mathrm{A}, \mathrm{B}$ and $\mathrm{C}$ identify the irrigated pixels that were not assigned to irrigation areas in the downscaled GMIA irrigation map.

\section{Results}

\subsection{Global analysis}

The new global irrigation map shows $18 \%$ more irrigated areas than the downscaled GMIA (Fig. 4). Overall, $3674478 \mathrm{~km}^{2}$ of irrigated areas have been identified, which is an increase of $659605 \mathrm{~km}^{2}$ compared to the downscaled GMIA (Fig. 5). The global result confirms the underestima- 


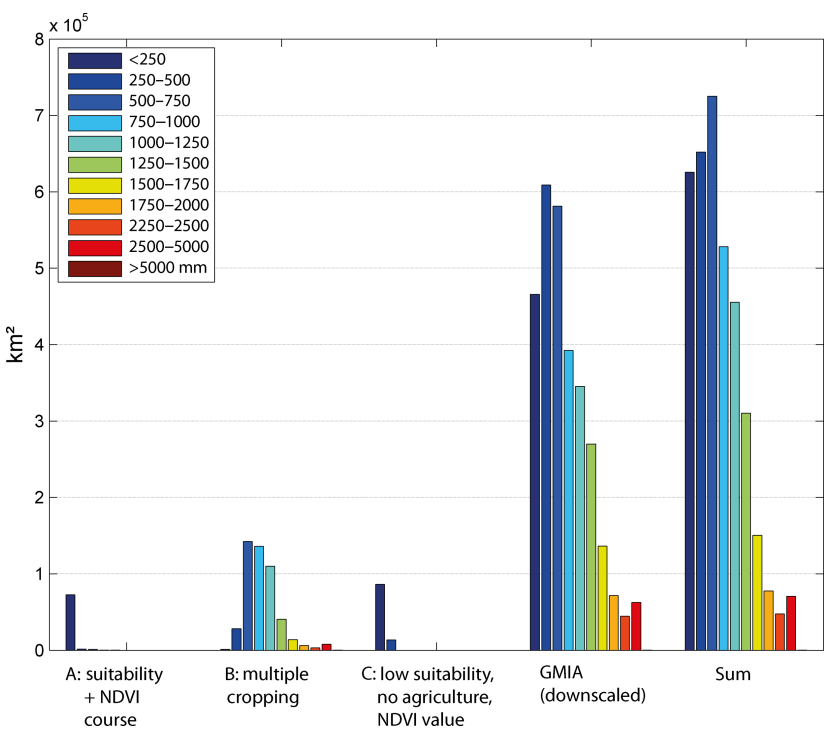

Figure 6. Yearly precipitation within the irrigated areas. Criteria A and $\mathrm{C}$ are suitable in dry regions, while criterion $\mathrm{B}$ identifies in humid regions as well. Further, irrigation decreases with increasing precipitation, but is also used in regions with high yearly precipitation.

tion of irrigated areas of Thenkabail et al. (2009a), who globally identified $3985270 \mathrm{~km}^{2}$ of irrigated area using a remotesensing-based approach, which is significantly higher than the results of Salmon et al. (2015) with $3141000 \mathrm{~km}^{2}$ and the global estimates of the FAO or of Siebert et al. (2005).

Figure 5 shows the global irrigated area additionally allocated through each of the criteria A, B and C of Sect. 2.5. The largest amount of additional irrigated area is identified by considering multiple cropping (B). In this case, $493123 \mathrm{~km}^{2}$ is not part of the downscaled GMIA. These areas are mainly found in Asia (Fig. 4), where according to our results, irrigation is often required for multiple cropping. An area of $100069 \mathrm{~km}^{2}$ is additionally identified because it is not suitable for crop cultivation but is classified as cropland (criterion C). By the use of criterion $\mathrm{A}, 76054 \mathrm{~km}^{2}$ is additionally allocated.

\subsection{Regional analysis}

The criteria A, B and C show different amounts of additional irrigated area for different regions. Criteria $\mathrm{A}$ and $\mathrm{C}$ identified irrigated areas mostly in arid and semi-arid regions, by comparing low or no suitability versus high NDVI. Figure 6 shows that additional irrigated areas by using $\mathrm{A}$ and $\mathrm{C}$ are mainly found in regions with annual precipitation $<500 \mathrm{~mm}$, according to the WorldClim data set for 1961-1990 (Hijmans et al., 2005).

In humid regions, criteria $\mathrm{A}$ and $\mathrm{C}$ are not sensitive, because agricultural suitability values in humid regions are high since precipitation is not limiting. We found that B extends

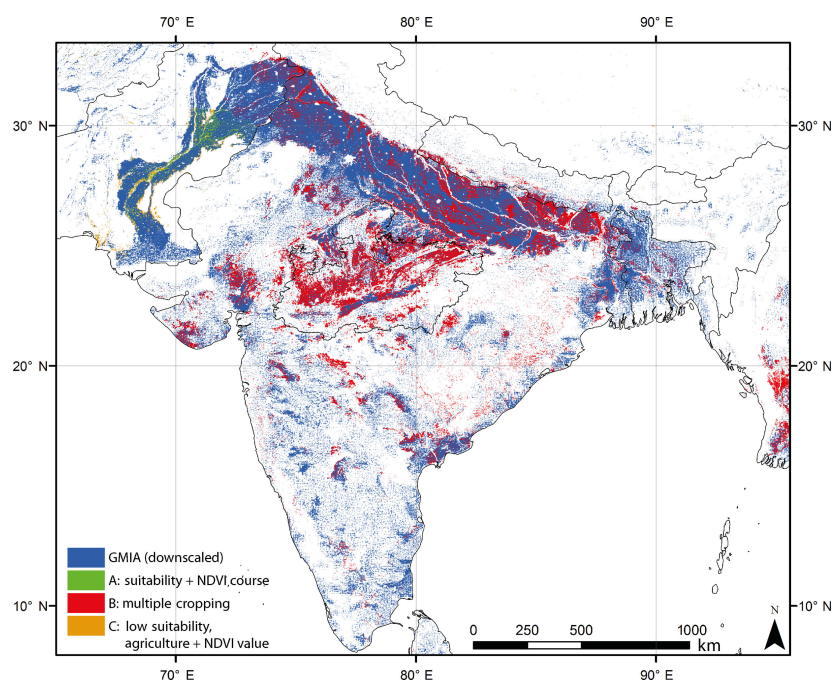

Figure 7. The Indian subcontinent and its identified irrigated areas. The blue areas are the information of the downscaled GMIA. Irrigation is more dense than expected in already irrigated regions and new areas appear in the state Madhya Pradesh.

irrigated areas in regions with low as well as high annual precipitation (Fig. 6), where irrigation is often used to allow for a second harvest. In total, Fig. 6 demonstrates that irrigation decreases with increasing precipitation, but irrigation does not only take place in dry regions. The largest amounts of new areas are in countries where irrigation plays an important role in agriculture. Irrigated areas seem to be denser in already irrigated regions.

\subsubsection{Asia}

The newly identified irrigated areas are mainly found in Asia, particularly in Central and Southeastern Asia. The countries with the largest amounts of additional area are India $\left(+267283 \mathrm{~km}^{2}\right)$ and China $\left(+149871 \mathrm{~km}^{2}\right)$. In these countries, irrigation plays a dominant role in agriculture, where $40 \%$ (India) and $57 \%$ (China) of the total cropland is irrigated according to statistics (FAO, 2016b). Nevertheless, statistics seem to largely underestimate irrigated areas, particularly in India. Here, we found on the one hand considerable additional irrigated areas compared to GMIA within regions that are sparsely irrigated, such as the state of Madhya Pradesh (Fig. 7). On the other hand, irrigated areas are additionally identified within regions that already show a high irrigation density, such as Uttar Pradesh along the foothills of the Himalaya, where even the density of irrigated areas increases in our results (Fig. 7). In these regions in particular, the irrigated areas were detected by comparing the potential vegetation cycles to the actual yearly NDVI course. Due to its seasonality, precipitation only allows for one harvest - a second harvest requires irrigation. Even legumes, which serve as nitrogen fertilizers, have to be irrigated. 
Within Asia, the developed method unveils large previously unknown irrigated areas in Kazakhstan $\left(+30661 \mathrm{~km}^{2}\right)$, Pakistan $\left(+26667 \mathrm{~km}^{2}\right)$, Myanmar $\left(+25212 \mathrm{~km}^{2}\right)$, Uzbekistan $\left(+17454 \mathrm{~km}^{2}\right)$ and Turkmenistan $(+13483)$. In Central Asia the irrigated areas along the rivers are particularly larger than previously reported. The Asian countries with the largest percentage difference compared to FAOSTAT (FAO, 2016b) statistical data (averaged from 1999 to 2012) are Mongolia $(+815 \%)$, Kazakhstan $(+183 \%)$, Myanmar $(+119 \%)$ and Yemen $(+103 \%)$.

\subsubsection{Africa}

Irrigation plays a minor role in the tropical regions of Africa, while there are contiguous irrigated regions along the Nile in Egypt and Sudan, some smaller irrigated areas within the Mediterranean countries and some irrigated areas within Southern Africa. The countries with the largest amount of additional irrigated areas are found in Somalia $\left(+6427 \mathrm{~km}^{2}\right)$, Egypt $\left(3867 \mathrm{~km}^{2}\right)$ and Ethiopia $\left(+3536 \mathrm{~km}^{2}\right)$. The irrigated regions along the Nile Delta are denser and result in an increase in irrigated area of $12 \%$ in Egypt. The African continent shows the highest percentage discrepancy when compared to FAOSTAT (averaged from 1999 to 2012; Table 4). Countries with the highest percentage differences compared to the statistics are Chad (+500\%), Somalia (315\%), Kenya $(311 \%)$ and Cameroon $(+243 \%)$.

\subsubsection{Europe}

The discrepancy between the downscaled GMIA and the new irrigation map in Europe is smaller than in the regions mentioned above. The largest differences exist in Italy $\left(+11059 \mathrm{~km}^{2}\right)$, Spain $\left(+5270 \mathrm{~km}^{2}\right)$ and Greece $\left(+3922 \mathrm{~km}^{2}\right)$. While the Po Valley, the largest contiguous irrigated region within Europe, does not show significant differences between the downscaled GMIA and our highresolution irrigation map, many additional areas on Sardinia and Sicily are detected. In Spain, the known irrigated areas near the Pyrenees are well captured by GMIA, but the intensely used agricultural area around Valladolid in the northwest of Spain in particular shows additional irrigated areas according to our results. The highest percentage difference compared to FAOSTAT is found for Bosnia and Herzegovina $(+500 \%)$, Croatia $(+220 \%)$, Montenegro $(+207 \%)$ and some other countries in Eastern Europe. The comparison of FAOSTAT to GMIA in these regions results in similar high differences, since the FAOSTAT data were obviously not used in the GMIA data. The highest percentage differences in Western Europe to FAOSTAT are found in Portugal (+41\%), Great Britain $(+28 \%)$, France $(+27 \%)$ and Italy $(+26 \%)$.

\subsubsection{America}

The position and extent of the large irrigated areas in North America in Fig. 4 are very consistent with the distributed
Table 4. The results of the new irrigation map compared to the downscaled GMIA and FAOSTAT (FAO, 2016b). The countries are grouped according to UN Geographical Regions (UN, 2013).

\begin{tabular}{|c|c|c|c|}
\hline Region & $\begin{array}{r}\text { New } \\
\text { irrigation } \\
\text { map } \\
\left(\mathrm{km}^{2}\right)\end{array}$ & $\begin{array}{r}\text { GMIA } \\
\text { downscaled } \\
\left(\mathrm{km}^{2}\right)\end{array}$ & $\begin{array}{r}\text { FAOSTAT } \\
1999-2012 \\
\left(\mathrm{~km}^{2}\right)\end{array}$ \\
\hline Africa & 163783 & 136826 & 137817 \\
\hline Eastern Africa & 38232 & 25194 & 24589 \\
\hline Middle Africa & 3820 & 1685 & 1692 \\
\hline Northern Africa & 89870 & 82853 & 83969 \\
\hline Southern Africa & 15844 & 15828 & 15956 \\
\hline Western Africa & 16018 & 11267 & 11611 \\
\hline Americas & 520446 & 500106 & 494988 \\
\hline Caribbean & 13267 & 13248 & 13346 \\
\hline Central America & 76072 & 73226 & 70638 \\
\hline South America & 133743 & 122695 & 135183 \\
\hline North America & 297365 & 290938 & 275822 \\
\hline Asia & 2675125 & 2094375 & 2147293 \\
\hline Central Asia & 165668 & 102861 & 99412 \\
\hline Eastern Asia & 799187 & 642388 & 664684 \\
\hline Southern Asia & 1284744 & 976866 & 1018484 \\
\hline Southeastern Asia & 252997 & 216052 & 213601 \\
\hline Western Asia & 172528 & 156209 & 151112 \\
\hline Europe & 269190 & 238939 & 262372 \\
\hline Eastern Europe & 83967 & 81799 & 109648 \\
\hline Northern Europe & 10227 & 10227 & 10015 \\
\hline Southern Europe & 130460 & 106134 & 104132 \\
\hline Western Europe & 44536 & 40780 & 38578 \\
\hline Oceania & 41844 & 41266 & 30673 \\
\hline Australia and New Zealand & 41821 & 41242 & 30525 \\
\hline Melanesia & 24 & 24 & 134 \\
\hline Micronesia & 0 & 0 & 3 \\
\hline Polynesia & 0 & 0 & 10 \\
\hline World & 3670390 & 3011512 & 3073142 \\
\hline
\end{tabular}

statistics of the downscaled GMIA. Only in the northwestern USA do our results show significantly more irrigated areas than GMIA. It is notable that additional identified irrigated areas are found next to already detected irrigated areas in California, northwest and midwest of the USA. Thus, density increases within irrigated agglomeration regions. The percentage differences compared to FAOSTAT are relatively low compared to the other continents (Table 4). The highest percentage difference is found in Chile $(+71 \%)$, Canada $(+41 \%)$, Mexico $(+12 \%)$ and Brazil $(+8 \%)$.

To demonstrate the effect of the high spatial resolution of the results, Fig. 8 shows the results for a particular area in the northwest USA (Oregon). The comparison of the new irrigation map at 30 arcsec resolution with the GMIA at 5 arcmin resolution demonstrates the improvement of the data (Fig. 8). The higher resolution allows for more precise identification of irrigated fields. Further, the additionally recognized irrigated areas that are not included in the GMIA data set match well with the underlying true-color satellite image. In this case it also shows that the resolution of 30 arcsec degree is suitable for field-scale irrigation mapping in this region. 

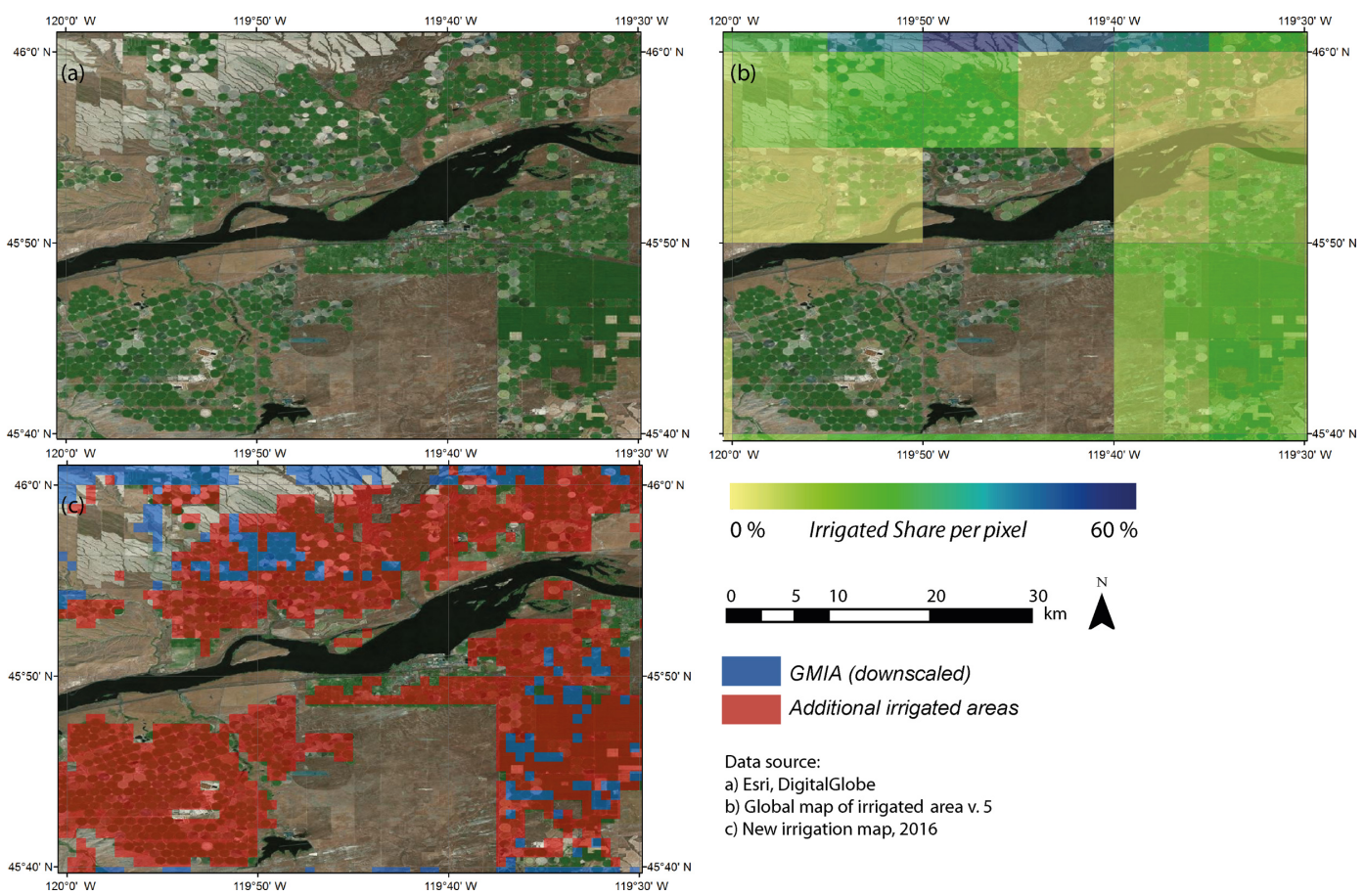

Figure 8. Small-scale analysis of the new irrigation map (c) and GMIA (b) in the USA compared to the raw satellite image (a).

\subsection{Differences between the downscaled GMIA and the original GMIA}

The downscaling process leads to differences between the downscaled and the original GMIA data. Since fractions of irrigated areas $<1 \%$ are not allocated to the finer resolution, they are neglected within the downscaling process. This leads to a global loss of irrigated area of $46329 \mathrm{~km}^{2}$. If there are no pixels available for distribution, e.g., due to excluded land such as forests, water bodies or urban areas, the irrigated area may not be allocated, which results in a global reduction of $19780 \mathrm{~km}^{2}$. Since we can only distribute integer values we additionally lose $2442 \mathrm{~km}^{2}$ through rounding the floating point numbers of the percentage share of the irrigated areas. Overall, we do not distribute $68551 \mathrm{~km}^{2}$ of irrigated areas, which is $2.28 \%$ of the GMIA data set at its original resolution. This small difference in percentages allows us to spatially compare the new irrigation map with the downscaled GMIA at the same spatial resolution, which is a result of the procedure described above.

\section{Validation}

The new irrigation map partially shows significant differences compared to the statistics and the resulting GIAM data set. No final truth exists on the amount and location of global irrigated area. Nevertheless, in order to validate the new highresolution irrigation map we compare our results to existing global and also regional studies. The comparison of ground truth data with the new irrigation map can also be a way to outline the differences between the new map and ground truth data. There are ground truth data available (European Environment Agency, 2014), providing point-specific land use information for specific regions, but they are rare and not always tagged with needed land use information like irrigation. Further, there are always scaling issues, concerning the spatial resolution, in comparing point information with spatial information. For the validation we decided to compare our map with the existing global data set IWMI-GIAM (Thenkabail et al., 2009a) and GRIPC (Salmon et al., 2015). Additionally we compare our results with regional studies in the USA (Ozdogan et al., 2010), China (Zhu et al., 2014) and India (Ambika et al., 2016), where we map the highest absolute differences compared to the statistical data and where irrigation is an important agricultural practice. Regional studies are able to develop approaches which consider local characteristics, while global studies have to transfer their methods to regions with completely different conditions. The global comparison is done on country level and the regional comparison on the level of states or provinces. For each country/state the irrigated area is calculated and compared to other studies.

\subsection{Global validation}

The resulting global irrigated area of 3.67 million $\mathrm{km}^{2}$ lies between the GRIPC results of 3.14 million $\mathrm{km}^{2}$ (Salmon et al., 2015) and IWMI-GIAM results of 3.98 million $\mathrm{km}^{2}$ (Thenkabail et al., 2009a). All three data sets show a larger 

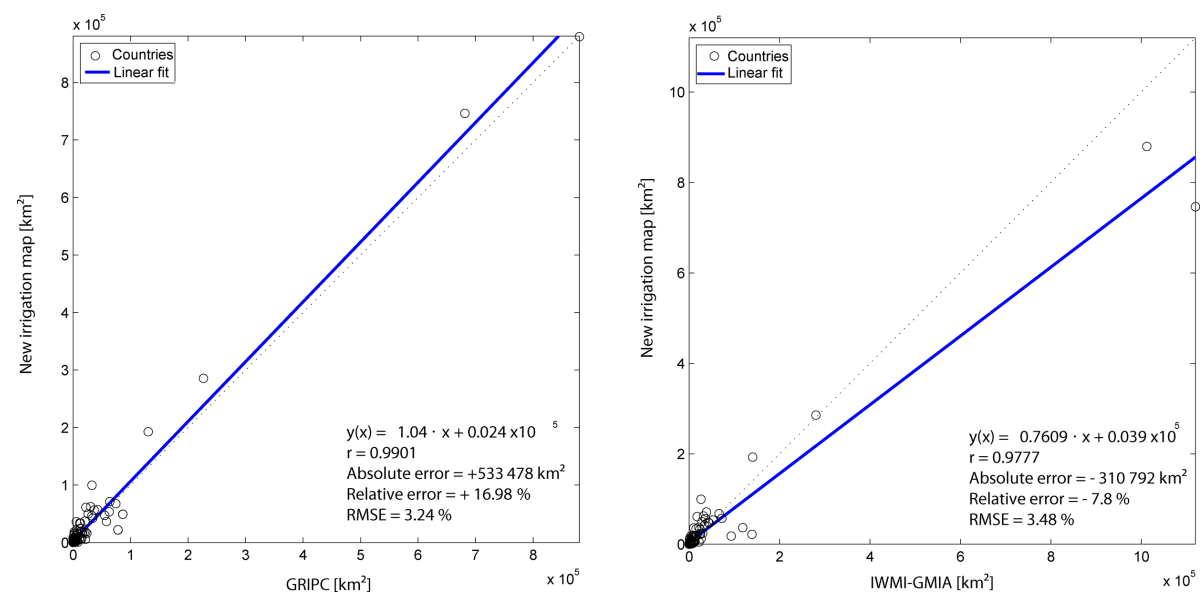

Figure 9. Regression plots of the two compared global data sets. The blue line is the linear fit and the dotted black line the linear equation.

irrigated area than reported by the statistics. Despite the absolute difference our new high-resolution map shows strong correlation with both data sets (IWMI-GIAM $r=0.97$; GRIPC $r=0.99$; Fig. 9) when correlating country values. The irrigated area is weighted by the size of the country. Thus, the deviations of the countries are comparable with each other. The slope shows a small overestimation of our results compared to GRIPC (1.04) and a larger underestimation of IWMI-GIAM (0.76). The regression plots also show the range of deviation (Fig. 9). The linear fit is strongly influenced by the high values and shows the underestimation of our results compared to IWMI-GIAM and overestimation compared to GRIPC (Fig. 9). The average difference per country is expressed in RMSE. The RMSEs of IWMI-GIAM $(3.48 \%)$ and GRIPC $(3.24 \%)$ are quite similar. The results of GRIPC (3.14 million $\mathrm{km}^{2}$ ) are very close to the official statistics $\left(3.07\right.$ million $\mathrm{km}^{2}$ ). GRIPC uses a regionally based field size factor which weights the size of the pixels. Without the field size factor the results show remarkably more irrigation ( 3.76 million $\mathrm{km}^{2}$ instead of 3.14 million $\mathrm{km}^{2}$ ). If we apply the GRIPC field size factor to our results, it changes the amount of irrigated area to 3.05 million $\mathrm{km}^{2}$. The use of field size factors can be a way to adjust regions characterized by small holder farms and heterogeneous landscapes. On the other hand it needs to be appropriately determined and validated, and it may create other sources of uncertainty.

\subsection{Regional validation}

The regional data suggest a strong linear correlation between our results and the regional studies described by the correlation coefficient: $r=0.94$ (USA), 0.84 (China) and $r=0.92$ (India; Fig. 10). The slope shows overestimation of our results compared to all other data sets. The RMSE was weighted by the size of the compared state and shows a small overestimation of our data set compared to the regional studies.
The difference between our results and the irrigated area in the USA given by Ozdogan et al. (2010) can be explained by the statistical areas used to derive our irrigation map. They are $25 \%$ larger than the corresponding areas of Ozdogan et al. (2010). Our map extends this area and results in $28.7 \%$ more irrigated area than given by Ozdogan et al. (2010). The regions where our analysis shows more irrigated areas are in the dry regions in the western USA and in the south (Table S1 in the Supplement). The largest irrigated areas in the USA are found in California, where we estimate $41816 \mathrm{~km}^{2}$ of irrigated areas. Ozdogan et al. (2010) calculate $26808 \mathrm{~km}^{2}$ of irrigated areas, while the United States Geological Survey (USGS) reports $42087 \mathrm{~km}^{2}$ of irrigated areas for the year 2010 (USGS, 2014). California is a good example of the different information about irrigated areas and the problems of validating irrigation maps. Even the official statistics for the year 2010 show two different values: the USGS states an irrigated area in California of $42087 \mathrm{~km}^{2}$, while the California Department of Water Resources (2010) reports $38033 \mathrm{~km}^{2}$. The example of California shows that the available statistics differ remarkably, which leads to strong impacts on the validation results. The water rights complaints in California regarding "Unauthorized Diversion" prove the existence of illegal irrigation activities (California Environmental Protection Agency, 2017), which are not part of the official statistics and are not only an issue of smallholder farmers or of watering lawns (Bauer et al., 2015). The comparison of our irrigation map with a study of irrigated areas in India shows a smaller relative error compared to the irrigation map of the USA. Overall the results are $138172 \mathrm{~km}^{2}$ higher than the results for India of Ambika et al. (2016). The differences could be caused by the different spatial resolution. The data of Ambika et al. (2016) are applied at a spatial resolution of $\sim 250 \mathrm{~m}$, which fits better to the small fields and the heterogeneous landscape of smallholder farms as they occur in India. 

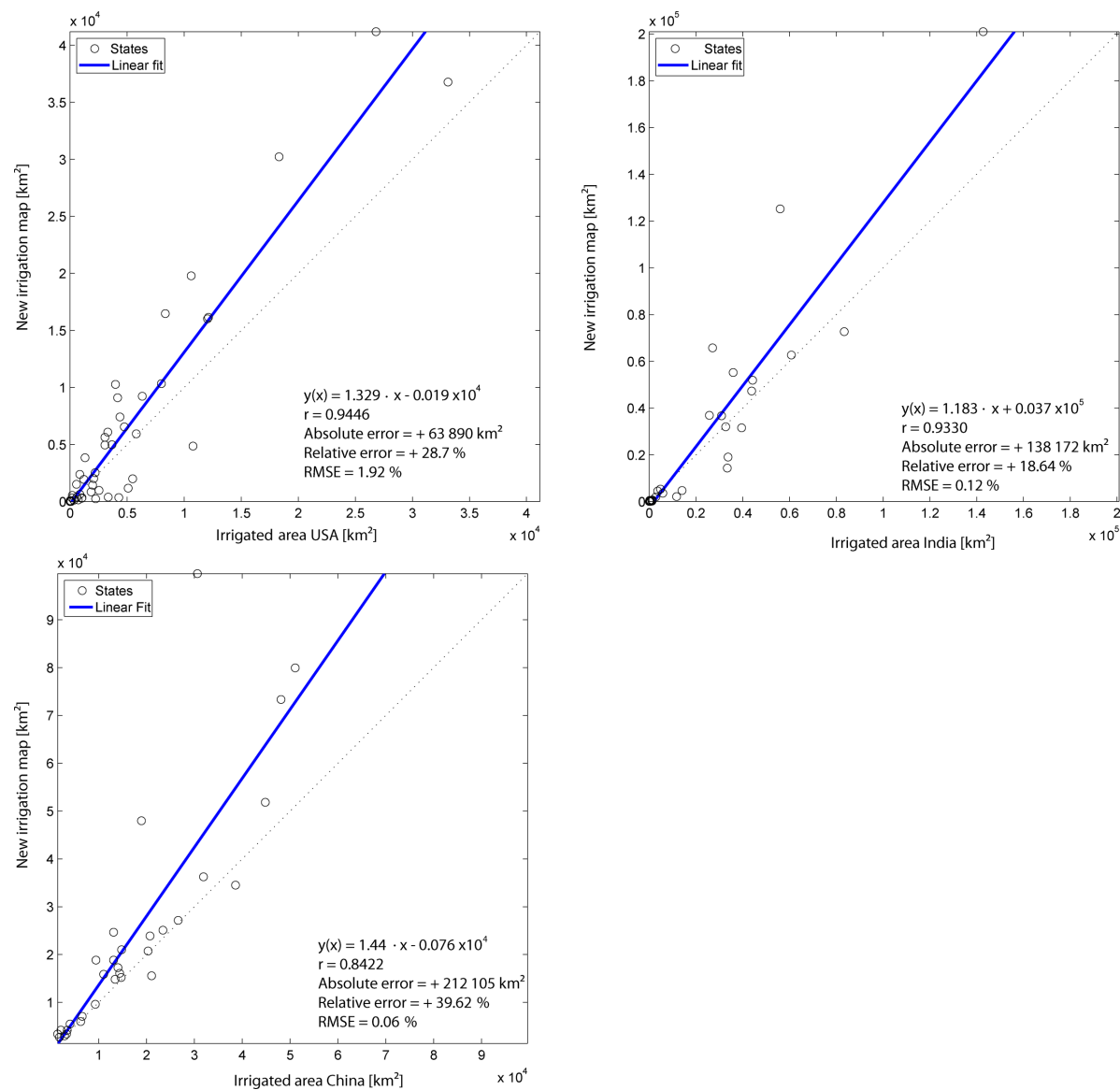

Figure 10. Regression plots of the compared our irrigation map compared to regional data sets of the USA (Ozdogan et al., 2010), India (Ambika et al., 2016) and China (Zhu et al., 2014). The blue line is the linear fit and the dotted black line the linear equation.

Zhu et al. (2014) developed an irrigation map of China that shows official statistics downscaled by using NDVI data. The differences compared to the new irrigation map are high and expectable, due to the restriction to the statistics. The highest differences are found in the province of Xinjiang (percentage and absolute) in the northwestern part of China. Xinjiang is characterized by a very dry continental climate. Nearly $90 \%$ of the area has less than $200 \mathrm{~mm}$ of precipitation per year (Hijmans et al., 2005). Therefore, agriculture is almost impossible without irrigation. Similar to the examples in the USA and in India, the distribution and the patterns of the irrigated areas fit the data of Zhu et al. (2014) but are denser. Irrigated areas seem to exceed the official numbers and confirm the results of previous studies on water allocation and water consumption in the Tarim Basin, where the water consumption exceeds the relevant water quotas (Thevs et al., 2015). The denser distribution of irrigated areas in the Tarim Basin shows the overuse of water despite the water quotas of the Chinese government and shows an underestimation of irrigated areas in the official reports.

\section{Discussion and conclusion}

This study focuses on the development of a new global irrigation map and its comparison with the most common irrigation maps on the global and regional scale. The results enable a high spatial resolution global view on the distribution of irrigated areas. The analysis indicates that the high-resolution view allows for the detection of additional irrigated areas, which were not covered by the existing data sets. This also increases the global estimate of irrigated land by $18 \%$ compared to the reported statistics.

Differences between irrigation maps result from the quality and the spatial resolution of the input data, the assumptions made and from the different terms and definitions of irrigated areas. The large differences between our results and the statistics in Central Asia (Mongolia, Kazakhstan) may result from classification errors in the underlying input data. Despite the high accuracy of the applied land use data sets, the ESA-CCI-LC and GlobCover land use classification include uncertainties which lead to errors in mapping irrigated areas. For example grassland, pastures or meadows are sometimes classified as cropland. Especially in dry regions, such 
as in Central Asia, this misinterpretation of cropland leads to a false classification of irrigated area. Further, since the collapse of the Soviet Union the cropping patterns of the independent countries of Central Asia has changed tremendously and fallow fields may influence the land use classification products through the present day.

The cropland area in the underlying land use data is not given as a proportional area of cropland within a pixel, which may also lead to an overestimation of cropland and thus also of irrigation.

The use of the agricultural suitability may lead to errors because it consists of 16 crops and may neglect, e.g., drought-resistant varieties or other species that are adapted to regional climatic conditions. Some typically irrigated crops are not considered in the crop suitability data, such as expensive (and therefore most likely irrigated) vegetables, olive trees, almond trees and irrigated pastures, which potentially leads to an underestimation of irrigated area. On a global scale, these areas are nevertheless assumed to be relatively small.

Errors in classifying irrigated areas could occur through high groundwater levels or the proximity to open water; plants could reach water sources through capillary rise or directly tap into the groundwater. This creates alternate water availability for the plants and can mimic irrigation in otherwise unsuitable locations.

A major reason for the differences between the irrigation maps lies in the different definitions of irrigated areas. While the FAO defines an irrigated area as an "area equipped for irrigation" (FAO, 2016b), the new irrigation map presented here classifies areas as irrigated if additional water (besides precipitation) is applied on a field. In some regions this may influence the result. For example in Bangladesh paddy fields are not considered as irrigated land as they cultivate mainly during the wet season and have no permanent irrigation infrastructure. The high differences in India may also result from the different definition, where 1999 only $47 \%$ of the total harvested area for paddy rice utilized permanent irrigation infrastructure (Frenken, 2012). The precipitation is harvested and concentrated on the paddy fields and used for rice cultivation by flood water recession (Frenken, 2012). Nonequipped cultivated wetlands, an upgrade of rain-fed cropland using soil moisture conservation, supplemental irrigation through water harvesting, non-permanent dug wells or water concentration may also result in irrigated area in the presented irrigation map (Molden, 2007). Due to the definition of "area equipped for irrigation" these areas are not part of the FAO irrigation class and accordingly not part of FAO related irrigation maps. This may influence the results particular in semi-arid and arid regions and in regions with small-scale and non-permanent irrigation systems (Frenken, 2012).

Compared with statistics and existing studies, our results show differences in both directions: underestimation and overestimation - depending on the reference data. The exam- ple of information on irrigated areas in the USA illustrates that the large discrepancies between the studies can be explained by the input data and the references.

The highest discrepancies to the statistics are generally found in developing countries. Possible reasons are inadequate statistics that may often also be a result of political interests (Thenkabail et al., 2009b). General uncertainties or inadequacies of agricultural statistics are well known in many developing countries and discussed in, for example, Young (1999) and Thenkabail et al. (2009b). The results suggest that not all irrigated areas are correctly reported in the official statistics. This indicates the existence of illegal or unregistered irrigation activities. The results also go along with previous analyses that showed large underestimation of irrigated areas in statistical data, especially for India (Thenkabail et al., 2009b) and Western Africa (Drechsel et al., 2006). Even the FAO recommends a careful handling of their official reports for countries in Central, Southern and Eastern Asia since many countries make no distinctions between rain-fed and irrigated cropland (Frenken, 2012, 2013). Independent survey techniques are strongly needed to verify the official statistics and reports.

The huge differences between estimated and reported irrigated areas demonstrate the need for further research in the field of irrigation mapping to get a more realistic picture of water withdrawal. The recent progress in the availability of remote sensing instruments through the Copernicus system of the EU (European Commission, 2017), which delivers weekly global high-resolution (10-20 m) coverage, improves the data availability for land use classifications and crop status analysis and is very promising for irrigation mapping.

Irrigation is important for increasing agricultural production (Smith, 2012): it reduces vulnerability of crop failures and increases food security and income (Bhattarai et al., 2002; Mengistie and Kidane, 2016). At the same time, more irrigated areas require more water, which is mainly taken from surface runoff and groundwater storage. This may increase the pressure in existing water resources and lead to an overuse of regionally available water resources which may threaten future agricultural activities (Du et al., 2014). Therefore, an accurate and more detailed inventory of irrigated areas is required to better estimate and manage available water resources to avoid overuse of water.

Data availability. Data are available at https://doi.pangaea.de/10. 1594/PANGAEA.884744.

Supplement. The supplement related to this article is available online at: https://doi.org/10.5194/hess-22-1119-2018-supplement.

Competing interests. The authors declare that they have no conflict of interest. 
Acknowledgements. This research was carried out within the framework of the GLUES (Global Assessment of Land Use Dynamics, Greenhouse Gas Emissions and Ecosystem Services) Project, which is supported by the German Ministry of Education and Research (BMBF) programme on Sustainable Land Management.

Edited by: Micha Werner

Reviewed by: two anonymous referees

\section{References}

Abuzar, M., McAllister, A., and Whitfield, D.: Mapping Irrigated Farmlands Using Vegetation and Thermal Thresholds Derived from Landsat and ASTER Data in an Irrigation District of Australia, Photogram. Eng. Remote Sens., 81, 229-238, 2015.

Alexandratos, N. and Bruinsma, J.: World agriculture towards 2030/2050: the 2012 revision, ESA working paper no. 1203, Global Perspective Studies Team, FAO Agricultural Development Economics Division, Rome, Italy, 2012.

Ambika, A. K., Wardlow, B., and Mishra, V.: Remotely sensed high resolution irrigated area mapping in India for 2000 to 2015, Sci Data, 3, 160118, https://doi.org/10.1038/sdata.2016.118, 2016.

Bauer, S., Olson, J., Cockrill, A., van Hattem, M., Miller, L., Tauzer, M., and Leppig, G.: Impacts of Surface Water Diversions for Marijuana Cultivation on Aquatic Habitat in Four Northwestern California Watersheds, PLoS ONE, 10, e0120016, https://doi.org/10.1371/journal.pone.0120016, 2015.

Bhattarai, M., Sakthivadivel, R., and Hussain, I.: Irrigation impacts on income inequality and poverty alleviation: Policy issues and options for improved management of irrigation systems, edited by: International Water Management Institute (IWMI), Colombo, 2002.

California Department of Water Resources: Agricultral Land and Water Estimates, http://www.water.ca.gov/landwateruse/ anlwuest.cfm (last access: 6 August 2017), 2010.

California Environmental Protection Agency: Water Rights Enforcement, http://www.waterboards.ca.gov/waterrights/ water_issues/programs/enforcement/complaints, last access: 6 August 2017.

Deryng, D., Elliott, J., Folberth, C., Muller, C., Pugh, T. A. M., Boote, K. J., Conway, D., Ruane, A. C., Gerten, D., Jones, J. W., Khabarov, N., Olin, S., Schaphoff, S., Schmid, E., Yang, H., and Rosenzweig, C.: Regional disparities in the beneficial effects of rising $\mathrm{CO}_{2}$ concentrations on crop water productivity, Nat. Clim. Change, 6, 786, https://doi.org/10.1038/nclimate2995, 2016.

Döll, P. and Schmied, H. M.: How is the impact of climate change on river flow regimes related to the impact on mean annual runoff? A global-scale analysis, Environ. Res. Lett., 7, 014037, https://doi.org/10.1088/1748-9326/7/1/014037, 2012.

Drechsel, P., Graefe, S., Sonou, M., and Cofie, O. O.: Informal Irrigation In Urban West Africa: An Overview, International Water Management Institute, Colombo, Sri Lanka, 2006.

Du, T., Kang, S., Zhang, X., and Zhang, J.: China's food security is threatened by the unsustainable use of water resources in North and Northwest China, Food Energy Secur., 3, 7-18, 2014.

European Commission: Copernicus - Europe's eyes on Earth, http: //www.copernicus.eu, last access: 3 February 2017.
European Environment Agency: Coordination of Information on the Environment (CORINE), http://land.copernicus.eu/ pan-european/corine-land-cover/clc-2012/view (last access: 2 February 2017), 2014.

ESA - European Space Agency: Bimonthly MERIS FR Composites - NDVI, https://www.esa.int/SPECIALS/Eduspace_Global_ EN/SEMQHINW91H_0.html (last access: 24 November 2016), 2007.

ESA - European Space Agency: GlobCover 2009, http://due.esrin. esa.int/page_globcover.php (last access: 24 November 2016), 2010.

ESA - European Space Agency: ESA CCI Land Cover, http://maps. elie.ucl.ac.be/CCI/viewer/index.php (last access: 24 November 2016), 2015.

Evans, R. G. and Sadler, E. J.: Methods and technologies to improve efficiency of water use, Water Resour. Res., 44, W00E04, https://doi.org/10.1029/2007WR006200, 2008.

FAO - Food and Agriculture Organization of the United Nations: Did you know ...? Facts and figures about, http:// www.fao.org/nr/water/aquastat/didyouknow/index3.stm (last access: 24 November 2016), 2014a.

FAO - Food and Agriculture Organization of the United Nations: Total Withdrawal by Sector, http://www.fao.org/nr/ water/aquastat/tables/WorldData-Withdrawal_eng.pdf (last access: 24 November 2016), 2014 b.

FAO - Food and Agriculture Organization of the United Nations: AQUASTAT, http://www.fao.org/nr/water/aquastat/data/ query/ (last access: 14 June 2016), 2016a.

FAO - Food and Agriculture Organization of the United Nations: FAOSTAT, http://faostat3.fao.org/download/Q/QC/E (last access: 14 June 2016), 2016b.

Foley, J. A., Ramankutty, N., Brauman, K. A., Cassidy, E. S., Gerber, J. S., Johnston, M., Mueller, N. D., O'Connell, C., Ray, D. K., West, P. C., Balzer, C., Bennett, E. M., Carpenter, S. R., Hill, J., Monfreda, C., Polasky, S., Rockstrom, J., Sheehan, J., Siebert, S., Tilman, D., and Zaks, D. P.: Solutions for a cultivated planet, Nature, 478, 337-342, 2011.

Frenken, K.: Irrigation in Southern and Eastern Asia in figures, edited by: AQUASTAT, Food and Agriculture Organization of the United Nations, Rome, 2012.

Frenken, K.: Irrigation in Central Asia in figures, edited by: AQUASTAT, Food and Agriculture Organization of the United Nations, Rome, 2013.

Fritz, S., See, L., McCallum, I., You, L., Bun, A., Moltchanova, E., Duerauer, M., Albrecht, F., Schill, C., Perger, C., Havlik, P., Mosnier, A., Thornton, P., Wood-Sichra, U., Herrero, M., Becker-Reshef, I., Justice, C., Hansen, M., Gong, P., Abdel Aziz, S., Cipriani, A., Cumani, R., Cecchi, G., Conchedda, G., Ferreira, S., Gomez, A., Haffani, M., Kayitakire, F., Malanding, J., Mueller, R., Newby, T., Nonguierma, A., Olusegun, A., Ortner, S., Rajak, D. R., Rocha, J., Schepaschenko, D., Schepaschenko, M., Terekhov, A., Tiangwa, A., Vancutsem, C., Vintrou, E., Wenbin, W., van der Velde, M., Dunwoody, A., Kraxner, F., and Obersteiner, M.: Mapping global cropland and field size, Global Change Biol., 21, 1980-1992, 2015.

Godfray, H. C., Beddington, J. R., Crute, I. R., Haddad, L., Lawrence, D., Muir, J. F., Pretty, J., Robinson, S., Thomas, S. M., and Toulmin, C.: Food security: the challenge of feeding 9 billion people, Science, 327, 812-818, 2010. 
Hijmans, R. J., Cameron, S. E., Parra, J. L., Jones, P. G., and Jarvis, A.: Very high resolution interpolated climate surfaces for global land areas, Int. J. Climatol., 25, 1965-1978, 2005.

Jägermeyr, J., Gerten, D., Heinke, J., Schaphoff, S., Kummu, M., and Lucht, W.: Water savings potentials of irrigation systems: global simulation of processes and linkages, Hydrol. Earth Syst. Sci., 19, 3073-3091, https://doi.org/10.5194/hess-19-3073-2015, 2015.

Jin, N., Tao, B., Ren, W., Feng, M., Sun, R., He, L., Zhuang, W., and Yu, Q.: Mapping Irrigated and Rainfed Wheat Areas Using Multi-Temporal Satellite Data, Remote Sensing, 8, 207, 2016.

Liu, J., Williams, J. R., Zehnder, A. J. B., and Yang, H.: GEPIC - modelling wheat yield and crop water productivity with high resolution on a global scale, Agricult. Syst., 94, 478-493, 2007.

Mankin, J. S., Viviroli, D. J., Singh, D., Hoekstra, A. Y., and Diffenbaugh, N. S.: The potential for snow to supply human water demand in the present and future, Environ. Res. Lett., 10, 114016, https://doi.org/10.1088/1748-9326/10/11/114016, 2015.

Mauser, W., Klepper, G., Zabel, F., Delzeit, R., Hank, T., Putzenlechner, B., and Calzadilla, A.: Global biomass production potentials exceed expected future demand without the need for cropland expansion, Nat. Commun., 6, 8946, https://doi.org/10.1038/ncomms9946, 2015.

Mengistie, D. and Kidane, D.: Assessment of the Impact of Small-Scale Irrigation on Household Livelihood Improvement at Gubalafto District, North Wollo, Ethiopia, Agriculture, 6, 1-22, 2016.

Molden, D.: Water for Food Water for Life: A Comprehensive Assessment of Water Management in Agriculture, Earthscan, London, Washington, D.C., 2007.

Neumann, K., Stehfest, E., Verburg, P. H., Siebert, S., Müller, C., and Veldkamp, T.: Exploring global irrigation patterns: A multilevel modelling approach, Agricult. Syst., 104, 703-713, 2011.

Ozdogan, M. and Gutman, G.: A new methodology to map irrigated areas using multi-temporal MODIS and ancillary data: An application example in the continental US, Remote Sens. Environ., 112, 3520-3537, 2008.

Ozdogan, M., Yang, Y., Allez, G., and Cervantes, C.: Remote Sensing of Irrigated Agriculture: Opportunities and Challenges, Remote Sensing, 2, 2274-2304, 2010.

Prasch, M., Mauser, W., and Weber, M.: Quantifying present and future glacier melt-water contribution to runoff in a central Himalayan river basin, The Cryosphere, 7, 889-904, https://doi.org/10.5194/tc-7-889-2013, 2013.

Rosenzweig, C., Elliott, J., Deryng, D., Ruane, A. C., Muller, C., Arneth, A., Boote, K. J., Folberth, C., Glotter, M., Khabarov, N., Neumann, K., Piontek, F., Pugh, T. A., Schmid, E., Stehfest, E., Yang, H., and Jones, J. W.: Assessing agricultural risks of climate change in the 21 st century in a global gridded crop model intercomparison, P. Natl. Acad. Sci. USA, 111, 3268-3273, 2014.

Salmon, J. M., Friedl, M. A., Frolking, S., Wisser, D., and Douglas, E. M.: Global rain-fed, irrigated, and paddy croplands: A new high resolution map derived from remote sensing, crop inventories and climate data, Int. J. Appl. Earth Obs. Geoinf., 38, 321-334, 2015.

Shahriar Pervez, M., Budde, M., and Rowland, J.: Mapping irrigated areas in Afghanistan over the past decade using MODIS NDVI, Remote Sens. Environ., 149, 155-165, 2014.
Siebert, S., Döll, P., Hoogeveen, J., Faures, J.-M., Frenken, K., and Feick, S.: Development and validation of the global map of irrigation areas, Hydrol. Earth Syst. Sci., 9, 535-547, https://doi.org/10.5194/hess-9-535-2005, 2005.

Siebert, S., Henrich, V., Frenken, K., and Burke, J.: Update Of The Digital Global Map Of Irrigation Areas to Version 5, Rheinische Friedrich-Wilhelms-University, Bonn, Germany/Food and Agriculture Organization of the United Nations, Rome, Italy, 2013.

Smith, M.: Yield response to water: the original FAO water production function, in: Crop yield response to water, edited by: Steduto, P., Hsiao, T. C., Fereres, E., and Raes, D., Food and Agriculture Organization of the United Nations, Rome, 2012.

Strzepek, K. and Boehlert, B.: Competition for water for the food system, Philos. T. Roy. Soc. Lond. B, 365, 2927-2940, 2010.

Sys, C. O., van Ranst, E., Debaveye, J., and Beernaert, F.: Land Evalutation: Part III Crop Requirements, Agricultural Publications, General Administration for Development Cooperation, Brussels, 1993.

Thenkabail, P. S., Biradar, C. M., Noojipady, P., Dheeravath, V., Li, Y., Velpuri, M., Gumma, M., Gangalakunta, O. R. P., Turral, H., Cai, X., Vithanage, J., Schull, M. A., and Dutta, R.: Global irrigated area map (GIAM), derived from remote sensing, for the end of the last millennium, Int. J. Remote Sens., 30, 3679-3733, 2009a.

Thenkabail, P. S., Dheeravath, V., Biradar, C. M., Gangalakunta, O. R. P., Noojipady, P., Gurappa, C., Velpuri, M., Gumma, M., and Li, Y.: Irrigated Area Maps and Statistics of India Using Remote Sensing and National Statistics, Remote Sensing, 1, 50-67, 2009b.

Thevs, N., Peng, H., Rozi, A., Zerbe, S., and Abdusalih, N.: Water allocation and water consumption of irrigated agriculture and natural vegetation in the Aksu-Tarim river basin, Xinjiang, China, J. Arid Environ., 112, 87-97, 2015.

Tilman, D., Balzer, C., Hill, J., and Befort, B. L.: Global food demand and the sustainable intensification of agriculture, P. Natl. Acad. Sci. USA, 108, 20260-20264, 2011.

UN - United Nations Statistics Divisions: Composition of macro geographical (continental) regions, geographical sub-regions, and selected economic and other groupings, http://unstats.un. org/unsd/methods/m49/m49regin.htm (last access: 24 November 2016), 2013.

UN - United Nations: Sustainable Development Goals, https: //sustainabledevelopment.un.org/sdgs, last access: 24 November 2016 .

USGS - US Geological Survey: Global Land Cover Characteristics Data Base Version 2.0, https://lta.cr.usgs.gov/glcc/globdoc2_0 (last access: 26 November 2016), 2000.

USGS - US Geological Survey: Estimate Use of Water in the United States in 2010, https://pubs.usgs.gov/circ/1405/ (last access: 2 September 2017), 2014.

Vörösmarty, C. J.: Global water assessment and potential contributions from Earth Systems Science, Aquat. Sci., 64, 328-351, 2002.

Vörösmarty, C. J. and Sahagian, D.: Anthropogenic disturbance of the terrestrial water cycle, Bioscience, 50, 753-765, 2000.

Wada, Y., Wisser, D., and Bierkens, M. F. P.: Global modeling of withdrawal, allocation and consumptive use of surface water and groundwater resources, Earth Syst. Dynam., 5, 15-40, https://doi.org/10.5194/esd-5-15-2014, 2014. 
Young, A.: Is there Really Spare Land? A Critique of Estimates of Available Cultivable Land in Developing Countries, Environ. Dev. Sustain., 1, 3-18, 1999.
Zabel, F., Putzenlechner, B., and Mauser, W.: Global agricultural land resources - a high resolution suitability evaluation and its perspectives until 2100 under climate change conditions, PLoS One, 9, e107522, https://doi.org/10.1371/journal.pone.0107522, 2014.

Zhu, X., Zhu, W., Zhang, J., and Pan, Y.: Mapping Irrigated Areas in China From Remote Sensing and Statistical Data, IEEE J. Select. Top. Appl. Earth Obs. Rem. Sens., 7, 4490-4504, 2014. 